\title{
Magdalena Pniewska
}

\section{Problematyka charakteru prawnego odpowiedzialności podmiotów zbiorowych za czyny zabronione pod groźbą kary w prawie polskim}

Problematyka odpowiedzialności podmiotów zbiorowych za czyny zabronione pod groźbą kary stała się przedmiotem szerokiej dyskusji w doktrynie prawa karnego w związku z wprowadzeniem do prawa polskiego instrumentów prawnych przewidzianych w Konwencji o ochronie interesów finansowych Wspólnot Europejskich, przyjętej przez Radę Unii Europejskiej 26 lipca 1995 roku oraz w Protokołach dodatkowych nr I i II do tej Konwencji.

Artykuł 3 wskazanej konwencji przewiduje bowiem pociąganie do odpowiedzialności karnej osób zarządzających przedsiębiorstwami. Zobowiązuje państwa członkowskie do podjęcia niezbędnych środków w celu ustanowienia, na zasadach określonych w prawie krajowym, odpowiedzialności karnej osób zarządzających przedsiębiorstwami lub innych osób w przedsiębiorstwie, posiadających prawo podejmowania decyzji lub wykonywania kontroli, za czyny stanowiące przestępstwo oszustwa na szkodę interesów finansowych Wspólnoty Europejskiej, popełnione przez osobę im podlegającą, działającą w imieniu przedsiębiorstwa. Artykuł 7 protokołu I poszerza katalog przestępstw na szkodę interesów finansowych Wspólnoty o przestępstwo korupcji czynnej, natomiast art. 12 protokołu II - o pranie pieniędzy. Wskazane przepisy nie zawierają czasownika określającego zachowanie osoby, która ma ponosić 
odpowiedzialność karną za stypizowane w nich przestępstwa. Oktawia Górniok określiła je terminem „dopuszcza”, który zawiera w sobie zarówno działanie sprowadzające się do współuczestniczenia w działaniu podległej osoby, jak i zaniechanie obowiązku przeszkodzenia jej w takim działaniu ${ }^{1}$.

Artykuł 3 protokołu II zobowiązuje państwa członkowskie do podjęcia środków umożliwiających pociąganie osób prawnych do odpowiedzialności. Przewiduje on, że każde państwo członkowskie podejmie niezbędne środki w celu ustanowienia odpowiedzialności osób prawnych za oszustwo, czynną korupcję i pranie pieniędzy popełnione w ich interesie przez jakąkolwiek osobę, działającą indywidualnie bądź wchodzącą w skład organu danej osoby prawnej, pełniącą funkcję kierowniczą na podstawie:

- pełnomocnictwa do jej reprezentowania lub

- uprawnienia do podejmowania decyzji w imieniu tej osoby prawnej, lub

- uprawnienia do sprawowania kontroli w obrębie tej osoby prawnej,

jak również za udział w popełnieniu, w charakterze współsprawcy lub podżegacza, przestępstwa oszustwa, korupcji czynnej lub prania pieniędzy oraz za usiłowanie popełnienia takiego oszustwa.

Poza wskazanymi powyżej sytuacjami, każde państwo członkwskie podejmie niezbędne środki w celu ustanowienia odpowiedzialności osób prawnych w przypadkach, gdy brak nadzoru lub kontroli sprawowanej przez jedną ze wskazanych wcześniej osób umożliwił podwładnemu popełnienie oszustwa, przestępstwa czynnej korupcji albo prania pieniędzy na korzyść tej osoby prawnej.

Odpowiedzialność osoby prawnej na podstawie omawianego przepisu nie stoi na przeszkodzie prowadzeniu postępowania karnego przeciwko osobom fizycznym będącym sprawcami, podżegaczami lub pomocnikami w przestępstwie oszustwa, czynnej korup-

1 O. Górniok, Ochrona Interesów Finansowych Wspólnot Europejskich. Komentarz, [w:] Prawo Wspólnot Europejskich a prawo polskie. Dokumenty Karne, red. E. Zielińska, Warszawa 2000, s. 271. 
cji lub prania pieniędzy (tzw. zasada równoległej odpowiedzialności za dany czyn karalny jego fizycznego sprawcy i osoby prawnej²).

Pojęcie osoby prawnej na tle omawianych przepisów należy wyjaśniać poprzez odniesienie do definicji przyjętych w krajowych porządkach prawnych. Nie będzie ono jednak zawierać w sobie państw i innych instytucji publicznych pełniących funkcje władcze oraz organizacji międzynarodowych prawa publicznego $\mathrm{w}$ związku $\mathrm{z}$ wyraźnym wyłączeniem dokonanym $\mathrm{w}$ art. 1 omawianego proto$\mathrm{kołu}^{3}$.

Dla pociągnięcia do odpowiedzialności osoby prawnej niezbędne jest wykazanie, że przestępstwo zostało popełnione w interesie lub dla korzyści osoby prawnej. Przedmiotem sporu jest, czy korzyść taką, doznaną lub zamierzoną przez fizycznego sprawcę, należy oceniać obiektywnie, ze względu na rzeczywisty interes osoby prawnej, czy też pierwszeństwo przy dokonywaniu tej oceny należy przyznać intencji, motywowi działania fizycznego sprawcy przestępstwa ${ }^{4}$.

Zwrot „funkcja kierownicza”, określający cechę fizycznego sprawcy, ma charakter ocenny, ale uściślają go kompetencje przysługujące na danym stanowisku. Każda $z$ nich pozwala na uznanie, że wchodzi ono w zakres tej nazwy ${ }^{5}$.

W ramach podstaw odpowiedzialności osób prawnych wyróżnić można także zachowanie polegające na uchybieniu obowiązkowi nadzoru lub kontroli przez scharakteryzowaną powyżej osobę, co umożliwia popełnienie przestępstwa przez osobę jej podległą. W ocenie O. Górniok taka regulacja stanowi nawiązanie do koncepcji K. Tiedemanna tzw. winy organizacyjnej jako podstawy zarzutu stawianego podmiotowi zbiorowemu, którego osobowe organy nie wypełniły obowiązku zabezpieczenia przed popełnianiem czynów karalnych przy wykonywaniu jego działalności ${ }^{6}$.

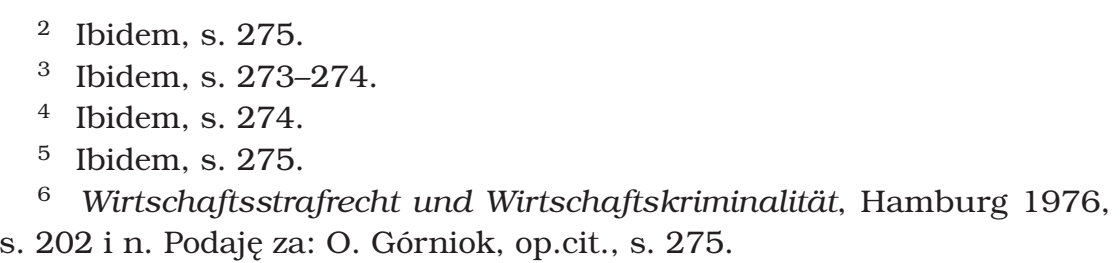


Istotne jest, że żadne $\mathrm{z}$ postanowień konwencji lub protokółów nie zawiera wyraźnego wskazania co do charakteru odpowiedzialności osoby prawnej. Jeden z poglądów zakłada, że jest to odpowiedzialność obiektywna i w związku z tym wśród jej podstaw nie wyróżnia się winy osoby prawnej. Tym samym nie ma tu zastosowania konstrukcja culpa in eligendo. Omawiana regulacja nie zawiera żadnych okoliczności ekskulpacyjnych. Co więcej, zwolennicy tego poglądu twierdzą, że przyjęcie jakiejkolwiek konstrukcji, która opierałaby się na winie osoby prawnej, spowodowałoby poważne ograniczenie zakresu odpowiedzialności tego podmiotu. Stąd kwestię zawinienia należy odnosić wyłącznie do działania sprawcy fizycznego ${ }^{7}$. Natomiast O. Górniok zauważyła, że omawiana odpowiedzialność nie może być w żadnym wypadku uznana za odpowiedzialność cywilną. Może to być natomiast odpowiedzialność administracyjna lub karna, w tym karna sądowa (kryminalna) lub karna administracyjna ${ }^{8}$.

Drugi protokół dodatkowy określa również sankcje stosowane wobec osób prawnych. I tak stosownie do art. 4 każde państwo członkowskie podejmie niezbędne środki w celu zagwarantowania, że osoba prawna podlega skutecznym, proporcjonalnym i odstraszającym sankcjom karnym, w tym karze grzywny, innej karze pieniężnej oraz ewentualnie innym sankcjom, takim jak:

- odebranie uprawnień do korzystania ze świadczeń lub pomocy publicznej,

- terminowy lub stały zakaz prowadzenia działalności gospodarczej,

- oddanie pod nadzór sądu,

- sądowy nakaz rozwiązania.

Ustawodawca zdecydował się na wprowadzenie do polskiego systemu prawnego powyższych instrumentów w kształcie nadanym im przez ustawę $z$ dnia 28 października 2002 roku o odpowiedzialności podmiotów zbiorowych za czyny zabronione pod groźbą kary9 .

7 A. Górski, A. Sakowicz, Zagadnienia prawnokarne integracji europejskiej. Traktatowy chaos czy ład prawny?, [w:] Wymiar sprawiedliwości Unii Europejskiej, red. M. Perkowski, Warszawa 2003, s. 328.

8 O. Górniok, op.cit., s. 276.

9 Dz.U. z 2002 r. Nr 197, poz. 1661. 
Od początku wskazana regulacja budziła szereg kontrowersji i sporów wśród przedstawicieli doktryny prawa karnego.

Zgodnie $\mathrm{z}$ art. 1 omawianej ustawy określa ona zasady odpowiedzialności podmiotów zbiorowych za czyny zabronione pod groźbą kary jako przestępstwa lub przestępstwa skarbowe oraz zasady postępowania w przedmiocie takiej odpowiedzialności. W art. 2 czytamy, że podmiotem zbiorowym w rozumieniu ustawy jest osoba prawna oraz jednostka organizacyjna niemająca osobowości prawnej, której odrębne przepisy przyznają zdolność prawną, z wyłączeniem Skarbu Państwa, jednostek samorządu terytorialnego i ich związków. Podmiotem zbiorowym w rozumieniu ustawy jest również spółka handlowa $z$ udziałem Skarbu Państwa, jednostki samorządu terytorialnego lub związku takich jednostek, spółka kapitałowa w organizacji, podmiot w stanie likwidacji oraz przedsiębiorca niebędący osobą fizyczną, a także zagraniczna jednostka organizacyjna. Natomiast art. 3 wprowadza zasadę, że podmiot zbiorowy podlega odpowiedzialności za czyn zabroniony, którym jest zachowanie osoby fizycznej, działającej w imieniu albo w interesie podmiotu zbiorowego w ramach uprawnienia lub obowiązku do jego reprezentowania, podejmowania w jego imieniu decyzji lub wykonywania kontroli wewnętrznej albo przy przekroczeniu tego uprawnienia, lub niedopełnieniu tego obowiązku, a także dopuszczonej do działania w wyniku przekroczenia uprawnień lub niedopełnienia obowiązków przez wskazaną powyżej osobę oraz działającej w imieniu albo w interesie podmiotu zbiorowego, za zgodą lub wiedzą tej osoby - jeżeli zachowanie to przyniosło lub mogło przynieść podmiotowi zbiorowemu korzyść, chociażby niemajątkową. Stosownie do treści art. 4 podmiot zbiorowy podlega odpowiedzialności, jeżeli fakt popełnienia czynu zabronionego, wymienionego w art. 16 ustawy, przez osobę, o której mowa w art. 3, został potwierdzony prawomocnym wyrokiem skazującym tę osobę, wyrokiem warunkowo umarzającym wobec niej postępowanie karne albo postępowanie w sprawie o przestępstwo skarbowe, orzeczeniem o udzielenie tej osobie zezwolenia na dobrowolne poddanie się odpowiedzialności albo orzeczeniem sądu o umorzeniu przeciwko niej postępowania z powodu okoliczności wyłączającej ukaranie sprawcy. W art. 5 wprowadzono zasadę, że podmiot zbiorowy podlega odpowiedzial- 
ności, jeżeli do popełnienia czynu zabronionego doszło w następstwie co najmniej braku należytej staranności w wyborze osoby fizycznej, o której mowa w art. 3 pkt 2 lub 3, lub co najmniej braku należytego nadzoru nad tą osobą ze strony organu lub przedstawiciela podmiotu zbiorowego.

Jako fundamentalne zagadnienie wymagające jednoznacznego rozstrzygnięcia jawi się na tle wskazanych powyżej regulacji przede wszystkim określenie charakteru prawnego tak skonstruowanej odpowiedzialności. Wątpliwości w tym przedmiocie wysuwane były już po uchwaleniu ustawy, ale nie ustały także po wydaniu przez Trybunał Konstytucyjny wyroku $z$ dnia 3 listopada 2004 roku, $\mathrm{K} 18 / 03^{10}$, ani po uchwaleniu ustawy $\mathrm{z}$ dnia 28 lipca 2005 roku o zmianie ustawy o odpowiedzialności podmiotów zbiorowych za czyny zabronione pod groźbą kary ${ }^{11}$. Jak wskazano bowiem powyżej, konwencja nie przesądziła, jaki ma być charakter odpowiedzialności, którą w oparciu o wprowadzone na jej podstawie instrumenty prawne mają ponosić podmioty zbiorowe.

W uzasadnieniu projektu ustawy wskazano pierwotnie, że odpowiedzialność podmiotów zbiorowych ma być odpowiedzialnością karną. Wprowadzenia odpowiedzialności podmiotów zbiorowych $\mathrm{w}$ takim kształcie nie uzasadniono jednakże szerzej. Twórcy projektu ograniczyli się jedynie do lakonicznego stwierdzenia, że „Projekt ustawy określa zasady odpowiedzialności podmiotów zbiorowych za przestępstwa lub przestępstwa skarbowe, oraz zasady postępowania w przedmiocie takiej odpowiedzialności" ${ }^{12}$. W toku prac nad projektem dokonano jednak zmiany, eliminując $z$ nazwy ustawy przymiotnik „karna” i zastępując go określeniem „odpowiedzialność za czyny zabronione pod groźbą kary”. Zmiana ta nie może jednak sama w sobie przesądzać o tym, $z$ jakiego rodzaju odpowiedzialnością mamy tu do czynienia.

10 OTK-A z 2004 r. Nr 10, poz. 103.

11 Dz.U. z 2005 r. Nr 180, poz. 1492.

12 Uzasadnienie rządowego projektu ustawy o odpowiedzialności karnej podmiotów zbiorowych (druk sejmowy nr 706). Historia prac nad projektem ustawy: http://ks.sejm.gov.pl/proc4/opisy/706.htm. 
W doktrynie zarysowały się, najogólniej rzecz ujmując, dwa stanowiska w tym przedmiocie. Pierwsze zakłada, że odpowiedzialność podmiotów zbiorowych wprowadzona do prawa polskiego omawianą ustawą jest w istocie odpowiedzialnością karną. Drugie prezentują natomiast przeciwnicy tego poglądu, którzy uznają, że omawianą ustawą wprowadzono do prawa polskiego nowy rodzaj odpowiedzialności o charakterze represyjnym, niebędący jednakże odpowiedzialnością stricte karną.

Opowiedzenie się za jednym ze wskazanych poglądów jest o tyle istotne, iż przyjęcie, że omawiana odpowiedzialność ma charakter karny, przesądza o tym, jakiej dyscypliny „instrumentarium” znajdzie do niej zastosowanie oraz jaki będzie zakres gwarancji w postępowaniu prowadzonym na podstawie przedmiotowej ustawy ${ }^{13}$. Rozstrzygnięcie tego sporu wymaga na wstępie przedstawienia zwięźle rysu historycznego dotyczącego odpowiedzialności karnej podmiotów zbiorowych w prawie europejskim.

Zasada societas delinquere non potest znana była co prawda prawu rzymskiemu, jednakże w późniejszych wiekach procesy karne przeciwko podmiotom zbiorowym były powszechnie spotykane. Odpowiedzialność zbiorową przewidywały bowiem prawa Eurico Jutlandii, prawo angielskie za panowania Edwarda Wyznawcy, a także w statutach Wintu, prawo kanoniczne, prawo średniowiecznej Hiszpanii, prawo Królestwa Obojga Sycylii, a także prawo polskie ${ }^{14}$. Dopiero w początkach XIX wieku większość autorów zaczęła wypowiadać się przeciwko odpowiedzialności karnej osób prawnych i w tym okresie zaczęła ona znikać z kodeksów karnych. Zdaniem J. Hirscha powodem tego był fakt, że we wskazanym okresie władza centralna umocniła się na tyle, że skazywanie na karę całych gmin lub miast nie było już potrzebne ${ }^{15}$. Od czasów Kodeksu bawarskiego przyjmowano za Feuerbachem, że podmiotem przestępstwa może być wyłącznie osoba fizyczna. Odpo-

13 D. Habrat, Materialnoprawne aspekty odpowiedzialności podmiotów zbiorowych $w$ polskim prawie karnym, Torun 2008, s. 102-103.

14 B. Namysłowska-Gabrysiak, Odpowiedzialność karna osób prawnych, Warszawa 2003, s. 25-26.

15 H.J. Hirsch, Problem odpowiedzialności karnej związków osób, Studia Prawnicze 1993, nr 4, s. 10. 
wiedzialność karna osób prawnych pojawiła się ponownie w prawie państw europejskich dopiero w latach 1887-1889 na skutek poglądów głoszonych przez Gierkego i Mestre'a ${ }^{16}$. W wieku XX odpowiedzialność karna osób prawnych czy też szerzej podmiotów zbiorowych została wprowadzona do porządku prawnego takich państw europejskich, jak Holandia, Anglia, Francja, Finlandia, oraz pozaeuropejskich, jak Stany Zjednoczone czy Kanada.

W nauce prawa karnego wskazuje się na istnienie trzech zasadniczych modeli odpowiedzialności karnej osób prawnych.

Jako historycznie najstarszy rysuje się model odpowiedzialności zastępczej, tzw. vicarious liability, oparty na teorii delegacji ${ }^{17}$. W tym modelu podmiot zbiorowy ponosi odpowiedzialność za czyny wszystkich osób, które działają na jego rzecz w ramach powierzonych im zadań, a także za czyny tych osób podjęte bezprawnie wbrew woli osoby powierzającej ich wykonanie, a nawet wyraźnie przez tę osobę zakazane. Założeniem tej koncepcji jest więc poniesienie przez podmiot zbiorowy obiektywnej odpowiedzialności za przestępstwo, którego znamion on sam nie zrealizował. Jest to więc jeden $z$ rodzajów odpowiedzialności obiektywnej, tzw. absolute liability. Oznacza on w praktyce pociągnięcie do odpowiedzialności karnej osoby, której czyn nie wypełnił znamion czynu zabronionego i której nie można także postawić zarzutu zawinienia. W rzeczywistości jest to więc odpowiedzialność za cudze czyny, jednakże mająca akcesoryjny charakter w stosunku do odpowiedzialności bezpośredniego sprawcy. Możliwość przypisania przestępstwa temu ostatniemu warunkuje bowiem pociągnięcie do odpowiedzialności podmiotu zbiorowego ${ }^{18}$. Omówiona koncepcja w niektórych państwach określana jest jako „działanie za kogoś innego”. Model ten funkcjonuje w Anglii i Kanadzie i znalazł on zastosowanie do przestępstw z grupy tzw. strict liability. Tę formułę odpowiedzialności stosuje się więc najczęściej do przestępstw $z$ dziedziny ochrony środowiska i prawa pracy ${ }^{19}$.

16 B. Namysłowska-Gabrysiak, Odpowiedzialność, s. 29.

17 B. Nita, Model odpowiedzialności podmiotów zbiorowych za czyny zabronione pod groźbą kary, Państwo i Prawo 2003, nr 6, s. 18.

18 Ibidem, s. 18-19

19 B. Namysłowska-Gabrysiak, Ustawa o odpowiedzialności podmiotów 
Z punktu widzenia tradycji polskiego prawa karnego, w szczególności oparcia odpowiedzialności na zasadzie winy, przeniesienie tego modelu do prawa polskiego wydaje się zabiegiem dość trudnym.

W systemie common law występuje również często model odpowiedzialności identyfikacyjnej, określanej także jako model alter ego, teoria controlling officer, teoria direct liability, teoria directing mind, teoria corporate organs ${ }^{20}$ czy też wreszcie teoria fikcji ${ }^{21}$. Jego założenie sprowadza się do uznania czynów osób będących w strukturze danej korporacji za czyny samej korporacji. Osobą fizyczną, którą utożsamia się z przedsiębiorstwem w ustawodastwach większości państw, jest organ przedsiębiorstwa, jego przedstawiciel, który działa $\mathrm{w}$ imieniu i na rzecz podmiotu zbiorowego (the scope of their authority and on behalf of the corporate body) ${ }^{22}$. Omawiany model opiera się więc na swoistej fikcji, że organy podmiotu zbiorowego stanowią jego „mózg”, reprezentują go i wyrażają jego wolę, stanowiąc tym samym „ego” podmiotu zbiorowego. Uznając więc, że organy podmiotu zbiorowego stanowią jego „mózg”, zarówno ich czyny, jak i wina zostają przypisane bezpośrednio podmiotowi zbiorowemu ${ }^{23}$. W takim ujęciu należy stwierdzić, że jest to odpowiedzialność podmiotu zbiorowego za własne, a nie za cudze czyny. Nie jest jednakże trafne nazywanie tego rodzaju odpowiedzialności „odpowiedzialnością bezpośrednią osób prawnych”. W przypadku bowiem gdy nie uda się zidentyfikować osoby fizycznej odpowiedzialnej za popełnienie danego czynu zabronionego, nie będzie można pociągnąć do odpowiedzialności podmiotu zbiorowego. Według B. Namysłowskiej-Gabrysiak model ten można co najwyżej określić jako odpowiedzialność pierwotną24. Można go współcześnie spotkać m.in. w ustawodastwach Francji, Anglii, Walii, Stanów Zjednoczo-

zbiorowych za czyny zabronione pod groźbą kary. Komentarz, Kraków 2004, s. 24-25.

20 Ibidem, s. 25-26.

21 B. Nita, op.cit., s. 18.

22 B. Namysłowska-Gabrysiak, Ustawa o odpowiedzialności podmiotów zbiorowych, s. 26.

23 B. Nita, op.cit., s. 19.

24 B. Namysłowska-Gabrysiak, Ustawa o odpowiedzialności podmiotów zbiorowych, s. 26-27. 
nych, Kanady i Australii ${ }^{25}$. W doktrynie wskazuje się niekiedy, że art. 3 ustawy z dnia 28 października 2002 roku o odpowiedzialności podmiotów zbiorowych za czyny zabronione pod groźbą kary nawiązuje do omawianej koncepcji.

Jako trzeci należy wymienić model bezpośredniej odpowiedzialności karnej podmiotów zbiorowych. W pierwszym ujęciu określany on jest jako model agregacji, tzw. aggregation doctrine lub collective knowledge, lub aggregation knowledge. Opiera się on na założeniu, że podmiot zbiorowy funkcjonuje w obrocie gospodarczym samodzielnie. W teorii przyjmuje się fikcję prawną, polegająca na tym, że zachowania poszczególnych osób wchodzących w skład podmiotu zbiorowego łączy się w jedną całość - zachowanie stanowiące podstawę odpowiedzialności osoby prawnej. W praktyce umożliwia to więc pociągnięcie podmiotu zbiorowego do odpowiedzialności nie tylko wtedy, gdy zachowania pojedynczych osób wchodzących w jego skład stanowią osobne przestępstwa, ale także wtedy, gdy każde z osobna nie stanowi przestępstwa, jednakże ich suma ma już taki charakter $^{26}$. Jest to więc odpowiedzialność podmiotu zbiorowego za jego własne czyny ${ }^{27}$. Ten model odpowiedzialności podmiotów zbiorowych występuje współcześnie w holenderskim prawie karnym, a także w systemach prawnych Stanów Zjednoczonych i Australii. Przyjęcie tej koncepcji jest o tyle atrakcyjne, że pozwala ona na pociągnięcie podmiotu zbiorowego do odpowiedzialności także wtedy, gdy zidentyfikowanie sprawcy bezpośredniego jest niemożliwe. Niemniej jednak model ten stanowi całkowite odejście od kanonów prawa karnego i czyni aktualną dyskusję dotyczącą istnienia tzw. winy zrzeszenia ${ }^{28}$. Warto zwrócić uwagę na to, że specyficzny model odpowiedzialności karnej podmiotów zbiorowych przewiduje kodeks karny Finlandii, gdzie stworzono pojęcie tzw. winy anonimowej (anonymous guilt), a bezpośrednią odpowiedzial-

25 Ibidem, s. 25.

26 Ibidem, s. 32.

27 B. Nita, op.cit., s. 19.

28 M. Filar, Z. Kwaśniewski, D. Kala, Komentarz do ustawy o odpowiedzialności podmiotów zbiorowych za czyny zabronione pod groźba kary, Toruń 2006, s. 23. 
ność osób prawnych skonstruowano przez odwołanie się do teorii obrony społecznej ${ }^{29}$.

Zwolennicy poglądu, że ustawa $\mathrm{z}$ dnia 28 października 2002 roku o odpowiedzialności podmiotów zbiorowych za czyny zabronione pod groźbą kary wprowadziła do prawa polskiego odpowiedzialność karną podmiotów zbiorowych wskazują na ustawę o porozumieniach kartelowych $z$ dnia 13 lipca 1939 roku jako przykład regulacji statuującej odpowiedzialność karną osób prawnych w prawie polskim. Ustawa kartelowa została uchwalona 28 marca 1933 roku, a następnie zmieniona przez ustawę nowelizującą $z$ dnia 13 lipca $1939 \mathrm{roku}^{30}$. Śliwiński, analizując tę regulację, stwierdził, że „Ustawa może w szczególności wprowadzić odpowiedzialność osoby prawnej jako takiej, czyniąc wyjątek od zasady, że przestępstwem jest czyn człowieka (osoby fizycznej)"31. Autor ten wskazywał, że art. 15 ustawy kartelowej groził grzywną za niedopełnienie zgłoszenia do rejestru kartelowego nie osobie fizycznej, lecz samej osobie prawnej. Artykuł 16 tej ustawy przewidywał natomiast możliwość wymierzenia kary grzywny lub aresztu za wykonywanie nieważnego porozumienia kartelowego przeciwko osobie prawnej. Śliwiński nie był pewny, czy przepisy części ogólnej kodeksu karnego mogą znaleźć zastosowanie do odpowiedzialności osoby prawnej. Postulował on, że „w dziedzinie winy należałoby chyba wyjść $\mathrm{z}$ zawinienia przedstawiciela danej osoby prawnej, nie można by więc mówić o odpowiedzialności karnej osoby prawnej, gdyby żadnemu z jej przedstawicieli nie można było przypisać winy (np. w razie niezgłoszenia do rejestru kartelowego skutkiem klęski żywiołowej, trzęsienia ziemi, działań wojennych itp.)"32.

Sąd Kartelowy natomiast w omawianej kwestii zajął następujące stanowisko:

29 B. Namysłowska-Gabrysiak, Ustawa o odpowiedzialności podmiotów zbiorowych, s. 32-33.

30 Dz.U. z 1939 r. Nr 63, poz. 418.

31 S. Śliwiński, Polskie prawo karne materialne, Warszawa 1946, s. 72 .

32 Ibidem. 
Jeżeli chodzi o ustawę o kartelach, to redakcja jej poszczególnych przepisów (np. art. 11), a także różnica w wysokości przewidzianej grzywny pomiędzy przepisami, które niewątpliwie dotyczą osób fizycznych, a temi, które mogą również dotyczyć osób prawnych, zdaje się wskazywać na to, że ustawa ta uznaje odpowiedzialność karną osób prawnych. Jeżeli przed nowelą z 27 listopada 1935 r., poz. 529/35 mogły co do tego powstawać wątpliwości, to znowelizowany tekst ust. 1 art. 11 rozwiewa je zupełnie, wskazując a contrario, że na karę grzywny może być skazana osoba prawna jako taka, a tylko karze aresztu podlegają jej reprezentanci. Wyjaśnia to ostatecznie, jaka była w tej mierze myśl ustawodawcy. Z tych względów Sąd Kartelowy uznaje, że odpowiedzialność karna osób prawnych w ustawie o kartelach jest przewidziana ${ }^{33}$.

Na tle omawianej regulacji także J. Makarewicz nie miał wątpliwości, że osoba prawna może być uznana za podmiot przestępstwa i przedmiot kary ${ }^{34}$. Wprowadzenie więc odpowiedzialności karnej podmiotów zbiorowych do prawa polskiego nie byłoby niczym nowym.

Tak więc za przyjęciem koncepcji, że ustawa $z$ dnia 28 października 2002 roku o odpowiedzialności podmiotów zbiorowych za czyny zabronione pod groźbą kary wprowadziła do polskiego systemu prawnego odpowiedzialność karną podmiotów zbiorowych, opowiadają się m.in. S. Waltoś ${ }^{35}$, B. Nita ${ }^{36}$ i B. Namysłowska-Ga-

33 Uzasadnienie do orzeczenia Sądu Kartelowego, OPA 1936, nr 1459, s. 345-346.

34 J. Makarewicz, Glosa do wyroku Sadu Kartelowego, OPA 1936, nr 1459, s. 360 i n.

35 S. Waltoś, Odpowiedzialność karna podmiotów zbiorowych - stary problem legislacyjny na nowo, [w:] Prawo. Społeczeństwo. Jednostka. Księga jubileuszowa dedykowana Profesorowi Leszkowi Kubickiemu, red. A. Łopatka, B. Kunicka-Michalska, S. Kielwicz, Warszawa 2003, s. 396-406 .

36 B. Nita, op.cit., s. 17. 
brysiak $^{37}$. Jednakże przeciwko tej koncepcji wypowiadają się m.in. M. Filar ${ }^{38}$, K. Wicher ${ }^{39}$, B. Mik ${ }^{40}$, A. Zachuta ${ }^{41}$ i R. Zawłocki ${ }^{42}$.

Zgoda panuje co do stwierdzenia, że przewidziana w ustawie odpowiedzialność ma niewątpliwie charakter represyjny, przy czym $z$ treści art. 6 wynika a contrario, iż ustawa ta nie statuuje odpowiedzialności cywilnej ani administracyjnej. Przyjęte w prawie karnym pojęcie czynu nie znajduje jednak zastosowania do omawianej odpowiedzialności, również wypracowane w prawie karnym pojecie winy nie daje się do niej odnieść, a ponadto ustawa nie określa znamiona czynu zabronionego (nie dokonuje jego typizacji $^{43}$. Barbara Nita zwraca jednak uwagę na fakt, że pojęcie odpowiedzialności karnej występuje nie tylko w ustawach karnych, ale i na gruncie Konstytucji, gdzie ma ono znaczenie autonomiczne, niezależne od treści, jaką nadaje mu k.k. Zdaniem tej autorki,

Definiując odpowiedzialność karną na poziomie konstytucyjnym nie można zatem wprost odwoływać się do kryteriów winy i czynu, jako elementów wyróżniających ten rodzaj odpowiedzialności. Taki zabieg umożliwiałby bowiem omijanie gwarancji konstytucyjnych dotyczących odpowiedzialności karnej, przez formalne kwalifikowanie jej w ustawach zwykłych jako inny rodzaj odpowiedzialności" ${ }^{44}$.

37 B. Namysłowska-Gabrysiak, Ustawa o odpowiedzialności podmiotów zbiorowych, s. 62 i n.

38 M. Filar, Z. Kwaśniewski, D. Kala, op.cit., s. 26.

$39 \mathrm{~K}$. Wicher, Zakres podmiotowy ustawy z dnia 28 października $2002 \mathrm{r}$. o odpowiedzialności podmiotów zbiorowych za czyny zabronione pod groźba kary - pojęcie podmiotu zbiorowego $w$ świetle wyroku Trybunału Konstytucyjnego z 3 listopada 2004 r., Radca Prawny 2005, nr 4, s. 73.

40 B. Mik, Charakter prawny odpowiedzialności podmiotów zbiorowych $w$ świetle ustawy z dnia 28 października 2002 r., Przegląd Sądowy 2003, nr 7-8, s. 67.

41 A. Zachuta, Specyfika odpowiedzialności podmiotów zbiorowych za czyny zabronione pod groźba kary, Prokuratura i Prawo 2003, nr 11, s. 147 i n.

42 R. Zawłocki, Prawo karne gospodarcze. Zarys Prawa, Warszawa 2007, s. $137-138$.

43 B. Namysłowska-Gabrysiak, Ustawa o odpowiedzialności podmiotów zbiorowych, s. 64.

44 B. Nita, op.cit., s. 17-18. 
Przedstawiciele doktryny uznający charakter karny odpowiedzialności podmiotów zbiorowych nie odnoszą więc do tego rodzaju odpowiedzialności stricte kodeksowego rozumienia pojęć czynu, winy i kary, które zostały sformułowane $z$ myślą o osobach fizycznych. O tym, że jest to odpowiedzialność karna, świadczy natomiast $\mathrm{w}$ ich ocenie bezsprzecznie represyjny charakter tej regulacji, oparcie postępowania w jej przedmiocie na przepisach k.p.k., a postępowania wykonawczego - na przepisach k.k.w., wymierzanie podmiotowi zbiorowemu kar określonych w ustawie, wprowadzenie instytucji znanych prawu karnemu, takich jak recydywa (art. 13), przedawnienie karalności (art. 14) czy przedawnienie wykonania kary (art. 15), a także zatarcie skazania (art. 43) ${ }^{45}$. Uznanie charakteru karnego ustawy opiera się zatem na całościowej wykładni wszystkich jej przepisów ${ }^{46}$.

Jednakże nie można mieć wątpliwości, że materialnoprawne przesłanki odpowiedzialności podmiotu zbiorowego w istocie rzeczy stanowią $z$ jednej strony przyniesienie przez przestępstwo osoby fizycznej korzyści podmiotowi zbiorowemu, chociażby niemajątkowej, lub przynajmniej możliwość osiągnięcia takiej korzyści, czyli przesłanka obiektywna, $z$ drugiej natomiast stwierdzenie po stronie podmiotu zbiorowego tzw. quasi-winy (art. 5), czyli przesłanka subiektywna. Zdaniem M. Filara omawiana ustawa określa więc samodzielnie, w oderwaniu od regulacji k.k., podstawy odpowiedzialności podmiotów zbiorowych ${ }^{47}$.

$Z$ drugiej strony za przyjęciem odpowiedzialności karnej podmiotów zbiorowych przemawiać mogą kryteria pozwalające uznać daną odpowiedzialność za odpowiedzialność karną, sformułowane w orzecznictwie Europejskiego Trybunału Praw Człowieka dotyczącym art. 6 Konwencji o ochronie praw człowieka i podstawowych wolności. Krzysztof Wojtyczek wskazuje na trzy kryteria stosowane przez Trybunał w celu ustalenia, czy dana sprawa jest sprawą karną. Pierwszym kryterium jest zakwalifikowanie tak danej sprawy

45 B. Namysłowska-Gabrysiak, Ustawa o odpowiedzialności podmiotów zbiorowych, s. 60-61.

46 Ibidem, s. 65.

47 M. Filar, Z. Kwaśniewski, D. Kala, op.cit., s. 42. 
przez system danego państwa, przy czym podkreśla się, że brak takiej kwalifikacji nie przesądza jeszcze, że dana sprawa nie jest sprawą karną. Drugie kryterium odnosi się do charakteru czynu lub zdarzenia stanowiącego podstawę odpowiedzialności. Duże znaczenie ma tu ustalenie, czy dana regulacja adresowana jest do określonej gruby osób, czy też na charakter generalny. Trzecie kryterium stanowi natomiast cel i surowość kary. Sprawa karna to bowiem taka sprawa, której celem jest zapewnienie przestrzegania określonej normy, oraz taka, która przekracza przy tym pewien stopień surowości ${ }^{48}$. W ocenie B. Namysłowskiej-Gabrysiak:

Przedstawione powyżej wszystkie trzy kryteria są całkowicie spełnione w przypadku odpowiedzialności przyjętej w ustawie o odpowiedzialności podmiotów zbiorowych [...] Po pierwsze, zgodnie $z$ ustawą są to sprawy karne, przekazane właściwym sądom rejonowym, wydziałom karnym. Po drugie, ustawa jest adresowana do szerokiej grupy podmiotów zbiorowych. I po trzecie, kary przewidziane w ustawie są karami bardzo surowymi, mającymi niewątpliwie na celu przestrzeganie określonych norm prawnych. Wobec powyższego należy stwierdzić po raz kolejny, iż ustawa o odpowiedzialności podmiotów zbiorowych [...] wprowadziła odpowiedzialność karną podmiotów zbiorowych co najmniej na poziomie konstytucyjnym ${ }^{49}$.

Jak zauważa M. Filar, brak jednak podstaw do przyjęcia, że jest to odpowiedzialność karna sensu stricto. Podstawą materialną odpowiedzialności karnej jest bowiem wyczerpanie przez podmiot przestępstwa ustawowych znamion opisanych w ustawie karnej. Przyjęta natomiast w omawianej ustawie konstrukcja uzależniająca odpowiedzialność podmiotu zbiorowego od uprzedniego skazania (lub innego prawomocnego orzeczenia, o którym mowa w art. 4 ustawy) osoby fizycznej sprawia, że mamy tu do czynienia $z$ odpowiedzialnością wtórną i pochodną. Odpowiedzialność podmiotu

48 K. Wojtyczek, Zasada wyłaczności ustawy $w$ sferze prawa represyjnego. Uwagi na gruncie konstytucji RP, CzPKiNP 1999, nr 1, s. 51 in.

49 B. Namysłowska-Gabrysiak, Ustawa o odpowiedzialności podmiotów zbiorowych, s. 71 . 
zbiorowego nie ma więc samoistnego charakteru. Brak zatem wymogu naruszenia przez podmiot ponoszący odpowiedzialność tzw. normy sankcjonowanej. Normę sankcjonowaną narusza osoba fizyczna określona w art. 3 ustawy. Tym samym przesłanki odpowiedzialności podmiotu zbiorowego nie odpowiadają przesłankom odpowiedzialności określonym w prawie karnym ${ }^{50}$.

Podobne stanowisko zajmuje A. Zachuta ${ }^{51}$. Wskazuje on, że odpowiedzialność podmiotów zbiorowych zbudowana jest na odmiennych zasadach niż odpowiedzialność osób fizycznych za przestępstwa i przestępstwa skarbowe. Przede wszystkim indywidualizacja winy i czynu, będąca istotą prawa karnego, nie przystaje do odpowiedzialności korporacyjnej. W ocenie tego autora żadna $z$ wypracowanych w doktrynie prawa karnego teoria czynu i winy nie nadaje się do zastosowania w stosunku do podmiotu zbiorowego. Odpowiedzialność podmiotu zbiorowego nie wynika bowiem $\mathrm{z}$ popełnionego przez niego przestępstwa. Tymczasem odpowiedzialności karnej podlega tylko ten, kto popełnia przestępstwo. Jak zauważa ten autor, warunkiem sine qua non odpowiedzialności podmiotu zbiorowego jest popełnienie przestępstwa lub przestępstwa skarbowego przez osobę fizyczną. Podmiot kolektywny odpowiada więc wtórnie dopiero wówczas, gdy osoba fizyczna wypełni swoim zachowaniem znamiona jednego z 121 typów czynów zabronionych, taksatywnie wymienionych w art. 16 ustawy, a określonych w innych ustawach $^{52}$. W konsekwencji A. Zachuta dochodzi do wniosku:

odpowiedzialność podmiotów zbiorowych przypomina odpowiedzialność karną, jest do niej zbliżona, ale nie może się z nią identyfikować. Jest to swoisty, odrębny i nawet autonomiczny rodzaj odpowiedzialności prawnej, a pewne podobieństwa do odpowiedzialności prawnej nie powinny tu być mylące. Przede wszystkim jest to odpowiedzialność za zindywidualizowany czyn zawiniony, który może być przypisany wyłącznie człowiekowi ${ }^{53}$.

50 M. Filar, Z. Kwaśniewski, D. Kala, op.cit., s. 41.

51 A. Zachuta, op.cit., s. 147 i n.

52 Ibidem, s. 152.

53 Ibidem, s. 153. 
W dyskusji nad charakterem odpowiedzialności karnej podmiotów zbiorowych zabrał głos także Trybunał Konstytucyjny. Poczynione przez niego ustalenia pozostawały jednakże w ścisłym związku z zagadnieniem przedstawionym Trybunałowi do rozstrzygnięcia. Tym samym jego spostrzeżenia w tej materii pozostawały niejako na marginesie rozważań podstawowych. W rezultacie uwagi poczynione przez Trybunał Konstytucyjny w uzasadnieniu wyroku $z$ dnia 3 listopada 2004 roku, K 18/03, nie rozwiały występujących na tym tle rozbieżności w doktrynie.

Trybunał ograniczył się bowiem do stwierdzenia:

Nie ma wątpliwości, że ustawodawca, uchwalając ustawę o odpowiedzialności podmiotów zbiorowych za czyny zabronione pod groźbą kary, dążył do stworzenia odrębnej podstawy odpowiedzialności. Odszedł od proponowanej w projekcie formuły: „ustawa o odpowiedzialności karnej podmiotów zbiorowych" i określił samodzielnie materialnoprawne zasady odpowiedzialności podmiotów zbiorowych i tryb postępowania [...]

Pomimo pewnych rozbieżności, jakie pojawiły się wśród interpretatorów ustawy o odpowiedzialności podmiotów zbiorowych za czyny zabronione pod groźbą kary, należy uznać, że regulacje tej ustawy określają odpowiedzialność o charakterze represyjnym. Świadczą o tym przesłanki tej odpowiedzialności, a przede wszystkim represyjny cel i funkcja orzekanych wobec podmiotów zbiorowych kar. Pominięcie przez ustawodawcę w tytule ustawy i jej treści bezpośredniego wskazania na „odpowiedzialność karną” podmiotów zbiorowych można tłumaczyć względami legislacyjnymi - użycie tego zwrotu obligowałoby bowiem do stosowania wprost części ogólnej kodeksu karnego ze względu na art. 116 k.k. („Przepisy części ogólnej tego kodeksu stosuje się do innych ustaw przewidujących odpowiedzialność karną, chyba że ustawy te wyraźnie wyłączają ich zastosowanie").

Odpowiedzialność karna jest tylko jedną $\mathrm{z}$ form odpowiedzialności, w związku z którą stosowane są środki o charakterze represyjnym. Ustawodawcy polskiemu znane są także inne formy postępowań o charakterze represyjnym, które nie są postępowaniami karnymi, $\mathrm{i}$ - co istotne - prowadzić je mogą (w początkowej przynajmniej fazie) 
organy niebędące sądami (wyrok TK z 4 lipca 2002 r., sygn. P 12/01, OTK ZU nr 4/A/2003, poz. 50, s. 731).

Dla rozpoznania niniejszej sprawy zasadnicze znaczenie ma nie tyle jednoznaczne „nazwanie” postępowania, z którym mamy do czynienia na gruncie ustawy, ile stwierdzenie, czy wobec charakteru zawartych w niej norm prawnych istnieje konieczność zastosowania w ramach tego postępowania gwarancji konstytucyjnych dotyczących odpowiedzialności karnej. [...]

Podobnie więc jak w wypadku odpowiedzialności dyscyplinarnej czy odpowiedzialności za wykroczenia, konstytucyjne standardy odnoszone do prawa karnego (represyjnego) mają zastosowanie także do odpowiedzialności podmiotów zbiorowych przewidzianej w zakwestionowanej ustawie. W szczególności przepisy ustawy podlegają ocenie z punktu widzenia zasady dostatecznej określoności prawa represyjnego, którą poza art. 42 Konstytucji można wywodzić z zasady ochrony zaufania do państwa i stanowionego w tym państwie prawa (art. 2 Konstytucji), a także $z$ punktu widzenia pozostałych gwarancji konstytucyjnych ustanowionych w art. 42 Konstytucji.

Niemniej jednak B. Namysłowska-Gabrysiak, komentując wskazane powyżej orzeczenie, stwierdziła, że w jej ocenie odpowiedzialność podmiotów zbiorowych o charakterze karnym obowiązuje co najmniej na poziomie konstytucyjnym ${ }^{54}$. Wyrok Trybunału Konstytucyjnego pozwala jednak na stwierdzenie, że omawiana ustawa wprowadziła nowy model odpowiedzialności sui generis, zbliżony do odpowiedzialności karnej sensu largo, mający charakter represyjny. Dokonane przez Trybunał Konstytucyjny ustalenie, że odpowiedzialność podmiotów zbiorowych nie jest odpowiedzialnością karną sensu stricto, nie wyklucza przyjęcia, że jest to albo odpowiedzialność karna sensu largo, albo nowy model odpowiedzialności prawnej sui generis, zbliżony do odpowiedzialności karnej sensu $\operatorname{largo} 0^{55}$.

54 B. Namysłowska-Gabrysiak, Konstytucyjność przepisów ustawy z 28.10.2002 r. o odpowiedzialności podmiotów zbiorowych za czyny zabronione pod groźbą kary, Monitor Prawniczy 2005, nr 9, s. 459 i n.

55 K. Wicher, Zakres podmiotowy ustawy, s. 74. 
Za określeniem tej odpowiedzialności jako odpowiedzialności karnej sensu largo opowiada się m.in. D. Habrat ${ }^{56}$. Krzysztof Wicher uważa jednak, że brak normy sankcjonowanej w omawianej ustawie, a także regulacja art. 5 wprowadzająca cywilistyczne rozumienie winy nie pozwalają uznać odpowiedzialności podmiotów zbiorowych nawet za odpowiedzialność karną sensu largo ${ }^{57}$. Pojęcia zarówno „winy w wyborze” (culpa in eligendo), jak i „winy w nadzorze" (culpa in custodiendo) zostały skonstruowane na użytek odpowiedzialności odszkodowawczej. Wiążą się one $z$ ponoszeniem odpowiedzialności za popełnienie deliktu, a więc przekroczenia cywilnoprawnego. Tym samym są one prawu karnemu jako takiemu obce. Jak zauważa M. Filar, wprowadzenie takiej konstrukcji do omawianej ustawy poważnie osłabia „karnistyczną” filozofię odpowiedzialności podmiotu zbiorowego ${ }^{58}$.

Odmiennie B. Mik podnosi, że odpowiedzialność podmiotów zbiorowych, uregulowana w omawianej ustawie, stanowi przede wszystkim przykład skorzystania przez ustawodawcę z przysługującej mu legitymacji do represjonowania bezprawia $z$ tytułu samej niesubordynacji wobec porządku prawnego, w oderwaniu od warunku czynu, winy i podziałów na „klasyczne” rodzaje odpowiedzialności oraz poza ustawami karnymi (tzw. obiektywna koncepcja odpowiedzialności). Stąd odpowiedzialność ta zasługuje na samodzielną pozycję w systemie źródeł prawa oraz na nazwę odpowiedzialności prawej swego rodzaju ${ }^{59}$.

Niemniej poza sporem pozostaje fakt, że omawiana ustawa nie zawiera żadnych odesłań do przepisów k.k. Tym samym stosowanie analogii umożliwiające odwołanie się do nich w kwestiach materialnoprawnych należy uznać za niedopuszczalne. Rozstrzygając o odpowiedzialności podmiotów zbiorowych, nie można zatem posił-

56 D. Habrat, op.cit., s. 106.

57 K. Wicher, Wszczęcie postępowania $w$ przedmiocie odpowiedzialności podmiotów zbiorowych $w$ świetle wyroku Trybunału Konstytucyjnego $z$ dnia 3 listopada 2004 r. oraz nowelizacji ustawy z dnia 28 lipca 2005 r. o odpowiedzialności podmiotów zbiorowych za czyny zabronione pod groźbą kary, Przegląd Sądowy 2006, nr 7-8, s. 143.

58 M. Filar, Z. Kwaśniewski, D. Kala, op.cit., s. 31.

59 B. Mik, op.cit., s. 67. 
kować się takimi instytucjami prawa karnego materialnego, jak interlokalne i intertemporalne prawo karne, formy zjawiskowe i stadialne czynu zabronionego, okoliczności uchylające bezprawność lub winę, wielość lub jedność czynów czy zasady wymiaru kary ${ }^{60}$. Ustawa nie pozwala bowiem w obecnym kształcie na stosowanie do odpowiedzialności w niej uregulowanej przepisów części ogólnej k.k. ${ }^{61}$

Przedmiotowa ustawa może być uznana za swego rodzaju podsumowanie wieloletniej dyskusji w doktrynie prawa karnego w sprawie możliwości i konsekwencji wprowadzenia do systemu prawa polskiego odpowiedzialności karnej podmiotów niebędących osobami fizycznymi. Jak zauważa R. Zabłocki, ustawa ta ma charakter pionierski i kompleksowy. Autor ten określa przyjęty przez ustawodawcę model odpowiedzialności jako „odpowiedzialność quasi-karną". Pojęcie to uważa on za bardziej adekwatne niż określenie „odpowiedzialność karna”, gdyż to ostatnie identyfikowane jest jako konsekwencja popełnienia czynu zabronionego. Tymczasem podmiot zbiorowy nie jest $\mathrm{w}$ istocie sprawcą przestępstwa, lecz wyłącznie podmiotem równolegle i posiłkowo odpowiedzialnym za osobę fizyczną, a tym samym „istotą wskazanego modelu odpowiedzialności nie jest przypisanie podmiotowi zbiorowemu (sprawstwa) przestępstwa, lecz wskazanie na odpowiednie powiązanie pomiędzy przestępstwem osoby fizycznej a związaną z nim odpowiedzialnością karną podmiotu zbiorowego"62.

Podsumowując przytoczoną powyżej dyskusję, mającą miejsce w doktrynie prawa karnego, należy stwierdzić, że nie można mieć wątpliwości, iż odpowiedzialność podmiotów zbiorowych w prawie polskim nie jest odpowiedzialnością karną sensu stricto. Co prawda z punktu widzenia nauki prawa karnego nic nie stało na przeszkodzie, aby w wykonaniu wskazanych zobowiązań międzynarodowych wprowadzić taką odpowiedzialność do naszego sytemu prawnego, niemniej ustawodawca nie zdecydował się na tak daleko idący krok.

60 M. Filar, Z. Kwaśniewski, D. Kala, op.cit., s. 42.

61 D. Habrat, op.cit., s. 106.

62 R. Zawłocki, op.cit., s. 137-139. 
Koncepcja odpowiedzialności karnej podmiotów zbiorowych jest niewątpliwie niezwykle interesująca i zważywszy na rolę, jaką podmioty te odgrywają w gospodarce rynkowej, zapewne okazałaby się bardzo użyteczna w zwalczaniu niepożądanych zjawisk związanych z działalnością tych podmiotów. Odpowiedzialność o tym charakterze przewidywało już zresztą polskie prawo okresu międzywojennego, czego najlepszym przykładem była omówiona już powyżej ustawa kartelowa. Ustawodawca zrezygnował jednakże $z$ możliwości przyjęcia takiego rozwiązania. Model zawarty w omawianej ustawie nie może być bowiem w żadnym razie utożsamiany $\mathrm{z}$ modelem identyfikacyjnym odpowiedzialności karnej, jaki funkcjonuje np. we Francji. Argumenty przytaczane przez zwolenników koncepcji odpowiedzialności karnej podmiotów zbiorowych nie są przekonujące. Podmiot zbiorowy ponosi bowiem odpowiedzialność nie za swój czyn, i to jedynie w wypadku uprzedniego pociągnięcia do odpowiedzialności osoby fizycznej. Koniecznie jest także wykazanie po stronie podmiotu zbiorowego swoistej quasi-winy, tj. winy w wyborze lub winy w nadzorze. Brak więc wprowadzenia w omawianej ustawie wymogu naruszenia przez podmiot ponoszący odpowiedzialność normy sankcjonowanej, przy jednoczesnym ujęciu winy w kategoriach nieznanych prawu karnemu, a wypracowanych w prawie cywilnym, uprawnia do przyjęcia, że jest to zupełnie nowy rodzaj odpowiedzialności, nieznany do tej pory prawu polskiemu.

Nie bez znaczenia dla rozstrzygnięcia kwestii charakteru prawnego odpowiedzialności podmiotów zbiorowych jest także stanowisko Trybunału Konstytucyjnego. Trybunał nie pokusił się co prawda o nazwanie rodzaju odpowiedzialności przyjętego w omawianej ustawie, stwierdził on jednakże $z$ całą stanowczością, podzielając pogląd prezentowany już wcześniej przez m.in. M. Filara, że nie jest to odpowiedzialność karna sensu stricto. Trybunał uznał przy tym, że jest to odpowiedzialność o charakterze represyjnym, a zatem znajdują do niej zastosowanie gwarancje przewidziane w art. 42 Konstytucji. Tym samym należy zgodzić się z M. Filarem, że nie jest to co prawda odpowiedzialność karna sensu stricto, ale niewątpliwie odpowiedzialność typu karnego. Kwestią drugorzędną jest nazwanie tej odpowiedzialności. Nie wydaje się także zasadnym uznanie tej odpowiedzialności za odpowiedzialność karną sensu largo. Nie 
pozwala bowiem na to przetransponowane do omawianej ustawy wprost $z$ prawa cywilnego pojęcie winy. Do przyjęcia wydaje się zaproponowane przez R. Zawłockiego określenie „odpowiedzialność quasi-karna”.

Bardziej istotne jednakże są praktyczne implikacje takiego stanowiska. Konsekwencją przyjęcia tej koncepcji jest odrzucenie możliwości stosowania do odpowiedzialności podmiotów zbiorowych uregulowanej w omawianej ustawie przepisów części ogólnej k.k. Trzeba bowiem zwrócić uwagę na treść art. 116 k.k., zgodnie z którym przepisy te znajdują zastosowanie do innych niż k.k. ustaw przewidujących odpowiedzialność karną, chyba że ustawy te wyraźnie wyłączają ich stosowanie. Zaakceptowanie stanowiska, zgodnie z którym omawianą ustawą wprowadzono do prawa polskiego odpowiedzialność karną podmiotów zbiorowych, oznaczałoby stosowanie w zakresie zagadnień materialnoprawnych uregulowania części ogólnej k.k., dotyczące m.in. winy czy czynu i to wprost, a nie odpowiednio, gdyż art. $116 \mathrm{k} . \mathrm{k}$. nie przewiduje takiego ograniczenia. Jednakże przyjęcie koncepcji, że nie jest to odpowiedzialność karna, a nowy rodzaj odpowiedzialności prawnej, nieznany dotychczas prawu polskiemu, pociąga za sobą wyłącznie możliwości stosowana instytucji prawa karnego materialnego w odniesieniu do odpowiedzialności podmiotów zbiorowych uregulowanej w omawianej ustawie. W takim wypadku bowiem art. 116 k.k. nie znajdzie zastosowania, natomiast w ustawie brak odesłania do części ogólnej k.k. Odrzucenie natomiast karnego charakteru odpowiedzialności podmiotów zbiorowych czyni nieuprawnionym posłużenie się $\mathrm{w}$ tym zakresie analogią. Podkreślić jednakże należy, że ten nowy rodzaj odpowiedzialności niewątpliwie musi być zaliczany do odpowiedzialności o charakterze represyjnym. W związku $\mathrm{z}$ tym konstytucyjne standardy odnoszone do prawa represyjnego znajdują także zastosowanie do odpowiedzialności podmiotów zbiorowych za czyny zabronione pod groźbą kary. Tym samym stosując przepisy omawianej ustawy, należy mieć na uwadze art. 42 Konstytucji, w szczególności wyrażoną w nim zasadę nullum crimen sine lege poenali anteriori, a także zasadę domniemania niewinności. Przyjąć więc należy, że omawiana ustawa w sposób wyczerpujący reguluje kwestie materialnoprawne związane $\mathrm{z}$ odpowiedzialnością podmiotów 
zbiorowych, jednakże zastosowanie w praktyce jej przepisów musi odbywać się z poszanowaniem konstytucyjnych gwarancji przewidzianych dla podmiotów pociągniętych do odpowiedzialności o charakterze represyjnym. Materialnoprawnymi przesłankami odpowiedzialności podmiotu zbiorowego są więc przyniesienie przez przestępstwo osoby fizycznej korzyści podmiotowi zbiorowemu, chociażby niemajątkowej, lub przynajmniej możliwość osiągnięcia takiej korzyści oraz stwierdzenie po stronie podmiotu zbiorowego tzw. quasi-winy. Dokonując wykładni tych pojęć, należy mieć na względzie uregulowania zawarte w omawianej ustawie. Pamiętać bowiem należy o tym, że ustawa ta w sposób autonomiczny reguluje problematykę odpowiedzialności podmiotów zbiorowych. Już na marginesie należy tylko wskazać, że konstytucyjne standardy przewidziane dla tworzenia przepisów statuujących odpowiedzialność represyjną, m.in. zasada dostatecznej określoności prawa represyjnego, obowiązują także w odniesieniu do przepisów omawianej ustawy. Niezachowanie ich skutkowało uznaniem przez Trybunał Konstytucyjny w wyroku $\mathrm{z}$ dnia 3 listopada 2004 roku, sygn. akt $\mathrm{K}$ 18/03, art. $4 \mathrm{w} \mathrm{zw} . \mathrm{z}$ art. 36 ust. 1 omawianej ustawy w jej pierwotnym brzmieniu, art. $5 \mathrm{w}$ zakresie dotyczącym art. 3 pkt 4, art. 7 , art. 17, art. 18, art. 20, art. 21 i art. 33 za niezgodne $z$ Konstytucją. Dostosowanie przepisów ustawy do standardów konstytucyjnych nastąpiło w ustawie $z$ dnia 28 lipca 2005 roku o zmianie ustawy o odpowiedzialności podmiotów zbiorowych za czyny zabronione pod groźbą kary.

W konkluzji podkreślić należy, że ustawodawca wprowadził do prawa polskiego zupełnie nowy rodzaj odpowiedzialności prawnej typu karnego. Można mieć jedynie wątpliwości, czy nie byłoby bardziej zasadne $z$ punktu widzenia potrzeb polityki kryminalnej wprowadzenie do prawa polskiego odpowiedzialności karnej podmiotów zbiorowych w oparciu o jeden $z$ modeli wypracowanych w systemach prawnych państw europejskich. Niestety, polski ustawodawca nie zdecydował się na tak daleko idące rozwiązanie. 


\section{Abstract \\ The Form of Corporate Liability for Offences in the Polish Criminal Law}

Corporate liability for offences was introduced to the Polish law by the Convention on the Protection of the European Communities' Financial Interests of the 26 July 1995 and also by the First and the Second Protocol to the Convention.

The Convention imposed on the Member States the obligation to apply certain measures to establish criminal liability of a person having a leading position in the legal person for the frauds against the European Communities financial interests. In the second protocol, however, there is a requirement to introduce corporate liability for such offences committed in the corporate interest by the person who has a power of representation of the legal person, an authority to take decisions on behalf of the legal person or an authority to exercise control within the legal person. None of the mentioned acts, however, involves the provision indicating the form of corporate liability.

In the Polish law there was adopted the Act of the 28 October 2002 called "The Liability of Collective Entities for Offences". The form of the liability established in this statute was controversial from the early beginning.

There are certain points which allows to accept the idea of criminal liability of collective entities. On the other hand, there are also reasons for which it is possible to claim that corporate liability established in the Polish law is a new form of liability, only similar to criminal liability.

Criminal liability of legal persons is very well known in criminal law area. Historically, the first introduced model of corporate liability was so called "vicarious liability". In the consequence, the legal person was sanctioned because a person with whom it had a bond, committed an offence. The other form of criminal liability was "direct liability" also called "the theory of controlling officer". The point of the mentioned theory was to accept the acts of a person who was in the structure of corporation as the acts of the corporation itself. The third conception was the aggregation doctrine, also known as "collective knowledge" or "aggregation knowledge". The meaning of that doctrine was an assumption that the actions taken by people who were the members of corporation, might be combined in one act of the corporation. Criminal liability of legal persons was introduced also in the Polish law by the Act of Cartel Agreements of the 13 July 1939.

It is beyond a discussion that the Act of the 28 October 2002 is a piece of repressive legislation. It is strongly emphasised that criminal nature of 
the mentioned statue results from the Constitution. Constitutional meaning of criminal liability, however, is not the same as in Criminal Code. The another point might be the jurisprudence of the European Court of Human Rights, which accepts a wider meaning of criminal case. On the other hand, in the view of the mentioned statue, the corporation does not commit itself an act which is forbidden as an offence but the responsibility of the corporation is a result of the act committed by its member. Thus, it is secondary liability. It is also claimed that "mens rea" and "actus reus" known in criminal law can not be attributed to corporate liability. Therefore it is justified to say that there has been created a new form of liability.

The similar approach seems to present the Constitutional Tribunal in the verdict of 3 November 2004, Case K 18/03. Nevertheless, some authors claim that the discussed statute has a criminal nature and it could be assessed as a pieces of Criminal Law sensu largo. Others point out that such institutions used in the statue as culpa in eliegndo or culpa in custodiendo contradict its criminal nature. It is beyond a discussion that the statute doses not refer to Criminal Code at all.

Considering all above, the more convincing is the idea of "quasi-criminal liability of corporations". That form of liability is a piece of repressive legislation. It is very similar to criminal law, but can not be counted to that branch of law.

Keywords: Corporate Liability for Offences, Polish Criminal Law, Collective Entities, Criminal liability of legal persons, the theory of controlling officer, the aggregation doctrine, secondary liability, quasi-criminal liability 